\title{
Two cases of leiomyomatosis peritonealis disseminata and review of the literature
}

\author{
Abstract \\ Leiomyomatosis peritonealis disseminata (LPD)is an extremely rare condition. Here we \\ present two cases of LPD in our hospital. We discuss the aetiology and treatment of this \\ disease.
}

Volume 6 Issue I - 2017

Xuechuan Han, Yang Fan, Yan Yu

Department of Gynecology and Obstetrics, Ningxia People's Hospital, China

Correspondence: Xuechuan Han, Department of gynecology and obstetrics, Ningxia People's Hospital,Yin Chuan, China,Tel 86095I-5920036, Email xuechuanhan1956@I63.com

Received: October 16, 2016 | Published: January 12, 2017

\section{Introduction}

Leiomyomatosis peritonealis disseminata (LPD) is an extremely rare condition. It is also referred to as disseminated peritoneal leiomyomatosis which is characterized by the presence of multiple peritoneal and subperitoneal nodules composed of bland smooth muscle cells. This disease was first described by Willson \& Peale. ${ }^{1}$ It was designated as LPD by Taubert et al. ${ }^{2}$ It was diagnosed mainly in the reproductive-aged females. But a few cases occur in postmenopausal women and in men. Since then, less than 200 cases have been reported in the literature. Here we present two cases of LPD in our hospital.

\section{Case series}

\section{Case I}

A 38 years old patient (granda1, para1, aborta0) admit to our hospital because of the gynecological ultrasound reveal a $5.0 \mathrm{~cm}$ mass in the pelvis. The patient present with no specific symptom. No abnormality was identified in the liver, spleen ultrasound. The heart and lung assessment no abnormality. In addition, cancer antigen 125 and epididymis protein 4 and alpha-fetoprotein in normal range. She underwent laparoscopical myomectomy for uterine fibroid in local hospital five years ago. During surgery a myoma with $5 \mathrm{~cm}$ diameter was identified in the posterior uterine wall. It was removed by morcellator. The post-operative pathology reported that rich in leiomyoma cells. 2 years later she had laparoscopical hysterectomy due to the relapse of the uterine fibroid in the other hospital. During surgery two myoma was identified in the uterine. The post-operative pathology reveal that leiomyoma and positive for alpha-smooth muscle antibody and desmin. The exploratory laparotomy was performed. During surgery myoma tubercle were identified on the surface of rectum. The size was about $6 \mathrm{~cm}$. There were no abnormalities in the omentum, mesentery, sigmoid colon, intestine and liver. The lesion excision was performed. The frozen section indicated mesenchymal tumor. The post-operation pathology determined a diagnosis of leiomyomatosis peritonealis disseminate with no mitosis and necrosis. The result of immunohistochemistry was mostly desmin,$+ \mathrm{SMA}+, \mathrm{ER}+, \mathrm{PR}+$. The patient was uneventful and monitor by fellow up. There is no recurrence in 60 months.

\section{Case 2}

A 34 years old patient (granda1, para1, aborta1) admit to our hospital because of the gynecological ultrasound reveal pelvic mass. The patient present with no specific symptom. The CA125 and epididymis protein 4 was normal. She had laparotomy hysterectomy and salpino-oophorectomy in other hospital because of uterine myoma 10 years ago. The final pathology revealed uterine leiomyoma. There were no abnormality in the heart and lung. The exploratory laparotomy was carried out. In numerous leiomyoma- like implants were present in the abdomen and pelvis. There were also prominent at the surface of multiple organs including the omentum, mesentery, sigmoid colon, and intestine. The size varied from a diameter of a few millimeters (miliary seeds) to that of $6 \mathrm{~cm}$. Partial omentectomy and palliative debulking of the large nodules and appendicectomy were performed. On histopathology all implanting tumors consisted predominantly of bland smooth muscle cells. On immunohistochemistry the tumor cells were mostly desmin,$+ \mathrm{SMA}+, \mathrm{ER}+, \mathrm{PR}+$. The final diagnosis was LPD. The patients was well and no recurrence in fellow up (48 months).

\section{Acknowledgments}

None.

\section{Conflicts of interest}

None.

\section{References}

1. Willson JR, Peale AR. Multiple peritoneal leiomyomas associated with agranulosa-cell tumor of the ovary. Am J Obstet Gynecol. 1952;64(1):204-208.

2. Taubert HD, Wissner SE, Haskins AL. Leiomyomatosis Peritonealis Disseminata; An Unusual Complication Of Genital Leiomyomata. Obstet Gynecol. 1965;25:561-574.

3. Tavassoli FA, Norris HJ. Peritoneal leiomyomatosis (leiomyomatosis peritonealisdisseminata): a clinicopathologic study of 20 cases with ultrastructural observations. Int J Gynecol Pathol. 1982;1(1):59-74.

4. Lim OW, Segal A, Ziel HK. Leiomyomatosis peritonealis disseminata associated with pregnancy. Obstet Gynecol. 1980;55(1):122-125.

5. Hoynck van Papendrecht HP, Gratama S. Leiomyomatosis peritonealis disseminata. Eur J Obstet Gynecol Reprod Biol. 1983;14(4):251-259.

6. Heinig J, Neff A, Cirkel U, et al. Recurrent leiomyomatosis peritonealis disseminata after hysterectomy and bilateral salpingo-oophorectomy during combined hormone replacement therapy. Eur J Obstet Gynecol Reprod Biol. 2003;111(2):216-218. 
7. Bristow RE, Montz FJ. Leiomyomatosis peritonealis disseminata and ovarian Brenner tumor associated with tamoxifen use. Int J Gynecol Cancer. 2001;11(4):312-315.

8. Kitazawa S, Shiraishi N, Maeda S. Leiomyomatosis peritonealis disseminata with adipocytic differentiation. Acta Obstet Gynecol Scand. 1992;71(6):482-484.

9. Barone A, Ambrosio MR, Rocca BJ, et al. Leiomyomatosis peritonealis disseminata: an additional case. Eur J Gynaecol Oncol. 1992;35(2):188191

10. Fasih N, Prasad Shanbhogue AK, et al. Leiomyomas beyond the uterus: unusual locations, rare manifestations. Radiographics. 2008;28(7):19311948.

11. Morizaki A, Hayashi H, Ishikawa M. Leiomyomatosis peritonealis disseminate with malignant transformation. Int $J$ Gynaecol Obstet. 1999;66(1):43-45.
12. Bekkers RL, Willemsen WN, Schijf CP, et al. Leiomyomatosis peritonealis disseminata: does malignant transformation occur? A literature review. Gynecol Oncol. 1999;75(1):158-163.

13. Heinig J, Neff A, Cirkel U, et al. Recurrent leiomyomatosis peritonealis disseminata after hysterectomy and bilateral salpingooophorectomyduring combined hormone replacement therapy. Eur J Obstet Gynecol Reprod Biol. 2003;111(2):216-218.

14. Ghosh K, Dorigo O, Bristow R, et al. A radical debulking of leiomyomatosis peritonealis disseminata from a colonic obstruction: a case report and review of the literature. J Am Coll Surg. 2000;191(2):212315 